\title{
PENGEMBANGAN MODEL PEMBELAJARAN MATEMATIKA YANG MENGEMBANGKAN KEMAMPUAN BERPIKIR KRITIS
}

\author{
Buhaerah \\ STAIN Parepare \\ buhaerahstain@gmail.com
}

\begin{abstract}
ABSTRAK
Masalah utama yang diangkat dalam penelitian ini adalah "bagaimana proses dan hasil pengembangan model pembelajaran matematika yang mengembangkan kemampuan berpikir kritis disingkat model PMBK yang valid, praktis, dan efektif?". Berpikir kritis didefinisikan sebagai proses intelektual untuk menjelaskan konsep, memecahkan masalah, dan membuat keputusan yang dapat dipercaya dan diyakini kebenarannya. Penelitian ini adalah penelitian pengembangan (research and development) yang mengacu pada modifikasi model pengembangan pendidikan dari Plomp, komponen-komponen model menurut Joyce \& Weil, dan kualitas produk pendidikan menurut Nieeven. Model PMBK yang diperoleh telah memenuhi kriteria valid, praktis dan efektif. Beberapa temuan khusus yang berkonstribusi dalam penelitian ini antara lain: (1) siswa menjelaskan konsep, dan prinsip belajar matematika, (2) siswa mengidentifikasi soal (diketahui, ditanyakan, kecukupan unsur), membuat model matematika, dan penyelesaiannya, (3) siswa memeriksa, memperbaiki, dan memberikan penjelasan setiap langkah algoritma pemecahan masalah, dan (4) siswa secara individu atau kelompok mempersentasikan pendapat/ide di depan kelas. Rekomendasi penelitian ini, antara lain: (1) model PMBK yang dikembangkan ini baru sampai pada tahap uji coba terbatas, oleh sebab itu untuk mengetahui keefektifannya pada lingkup lebih luas, disarankan kepada para peminat untuk mengimplementasikannya di sekolah-sekolah. (2) aspek-aspek berpikir kritis siswa yang diterapkan dalam model PMBK ini dapat dimodifikasi oleh para guru yang berminat menerapkan model ini, modifikasi dapat dilakukan dengan cara menyesuaikan lingkungan dan budaya siswa. Dengan demikian perangkat-perangkat model PMBK juga turut termodifikasi.
\end{abstract}

Kata Kunci : model pembelajaran matematika, dan berpikir kritis.

\section{PENDAHULUAN}

Kemampuan berpikir kritis merupakan salah satu tujuan dalam pembelajaran matematika (Stacey, 2013; King \& Goodson, 2010; dan Ghokhale, 2005). Kemampuan berpikir kritis saat ini dibutuhkan oleh siswa untuk meningkatkan kualitas hasil pemikiran dan daya pikir intelektual yang original (Gokhale, 2005; dan Paul \& Elder, 2005). Pemerintah juga menetapkan agar setiap pengelola pembelajaran membekali siswa kemampuan berpikir kritis sebagai kompetensi masa depan (Kemdikbud, 2013:1). Sedangkan Ruggiero (2012) menyatakan bahwa berpikir kritis merupakan aktivitas mental untuk menilai kebenaran argumen, mengajukan pertanyaan, dan mengevaluasi. Sejalan 
pendapat Fisher (2001) menyatakan bahwa berpikir kritis adalah menginterpretasi, mengevaluasi hasil pengamatan, berkomunikasi, dan berargumentasi.

Berkaitan kemampuan berpikir kritis sebagai tujuan pembelajaran matematika, tampaknya masih jauh dari kenyataan. Hal ini terlihat dari beberapa penelitian pendahuluan menunjukkan bahwa kemampuan berpikir kritis masih jauh dari harapan, diantaranya; sebagian besar atau 80\% dari mereka belum mengetahui langkah-langkah yang harus ditempuh untuk sampai pada jawaban yang disertai data-data dan bukti-bukti pendukung, serta alasan cara memperolehnya. Selain itu, siswa mengalami kesulitan untuk menentukan nilai benar atau salah suatu argumen dan memberikan penjelasan dengan katakatanya sendiri. Salah satu penyebabnya adalah kurannya informasi yang diketahui siswa terkait menyusun argumen, dan cara mengkomunikasikannya.

Berkaitan berpikir kritis sebagai tujuan pembelajaran matematika, beberapa peneliti melaporkan bahwa mengembangkan kemampuan berpikir kritis kurang mendapat perhatian sepenuhnya dari kalangan guru maupun siswa. Mason, Burton, \& Stacey (2010), Ennis (2007), Nurdin (2007), dan Rofiq (2006) menyatakan bahwa tidak sedikit guru pada praktek pembelajaranya menyajikan materi, dan memberikan contoh-contoh kepada siswa. Akibatnya proses mengkonstruksi materi kurang berhasil, dan ada kecenderungan para siswa untuk dibimbing atau diberikan petunjuk penyelesaian masalah secara lengkap. Demikian juga, Berki \& Valtanen (2007), dan Stacey (2013) menyatakan bahwa sebagian besar siswa tidak mengambil makna dari proses penyelesaian. Sehingga pengetahuan yang seharusnya dimiliki siswa untuk berpikir kritis, belum sepenuhnya dikuasai.

Proses pembelajaran yang mendukung pengembangan kemampuan berpikir kritis dapat dilakukan dengan cara membelajarkan siswa membuat dan menyusun argumen, khususnya pada kegiatan-kegiatan pemecahan masalah, perkembangan intelektual, kerja individu, dan kerja kelompok (Dickerson \& Doerr, 2008; Beagle, 1979; Bell, 1978; dan Innabi, 2003). Kegiatan-kegiatan lain yang mendukung pengembangan kemampuan berpikir kritis, yaitu; menjustifikasi informasi, mengidentifikasi konsep, dan menyajikan bukti-bukti pendukung (Rantzer \& Byrnes, 2003; Reys \& Lindquist, 2013; Innabi, 2003; Ruggiero, 2012; Gokhale, 2005; Paul \& Elder, 2005).

Argumen yang dimaksud dalam berpikir kritis adalah argumen yang didukung oleh bukti-bukti dan data-data yang relevan dengan permasalahan, serta tersusun secara logis, sehingga kebenarannya dapat dipercaya dan diyakini (Ruggiero, 2012; dan Watson \& Glaser, 2008). Sejalan pendapat Innabi (2003), dan Paul \& Elder (2008) bahwa argumen 
yang baik tersusun dengan penuh pertimbangan, memenuhi kriteria kelayakan, dan disertai alasan-alasan yang mendukung, serta mengandung solusi atas permasalahan. Demikian juga Gokhale (2005), dan Duron, Limbach, \& Waugh (2006) menyatakan bahwa algoritma yang dilengkapi argumen atau alasan cara memperolehnya lebih mudah dipahami dan diyakini kebenarannya. Jadi belajar menyusun dan mengkaji argumen akan memberi peluang terbentuknya kemampuan berpikir kritis.

Berkaitan belajar menyusun dan membuat argumen, Dickerson \&Doerr (2008) menyatakan bahwa guru sebaiknya membiasakan siswa mengidentifikasi dan menjustifikasi informasi dengan cara membuat alasan-alasan yang logis dan sistematis. Sehingga kebimbangan-kembingan yang kadang menghambat seseorang naik pada level berpikir yang lebih tinggi mudah diatasi. Demikian juga, Bajracharya (2010) menyatakan bahwa membuat dan menyusun argumen untuk membangun pengetahuan berdampak terhadap kemampuan seseorang dalam memecahkan masalah. Sejalan pendapat Ennis (2008) menyatakan bahwa pemecahan masalah yang didukung bukti-bukti yang relevan, akan memudahkan seseorang memiliki kemampuan berpikir kritis. Dengan demikian, perlu ada upaya memaksimalkan seluruh potensi pada diri siswa belajar membuat dan menyusun argumen, serta mengurangi keterlibatan guru dalam menyajikan materi.

Beberapa peneliti telah mengembangkan model pembelajaran yang mengembangkan kemampuan berpikir kritis, diantaranya; Marcut (2005), Watson \& Glaser (2008), dan Bajracharya (2010). Marcut (2005:57) mendesain model atau pola pembelajaran dengan cara menciptakan kondisi pembelajaran yang kondusif, seperti; membangun komunikasi dalam mengekspresikan ide-ide, mendengarkan dan memperhatikan teman yang menyampaikan ide-ide, menunjukkan minat terhadap ide-ide itu, bekerja secara berkelompok untuk mencapai tujuan bersama. Watson \&Glaser (2008:3) mendesain model pembelajaran yang mengkombinasikan sikap, pengetahuan, dan keterampilan untuk mengembangkan kemampuan berpikir kritis. Sikap berkenaan upayaupaya untuk mengenali masalah dan mencari bukti-bukti pendukung. Pengetahuan terkait generalisasi, proses abstraksi, dan pengambilan kesimpulan yang valid. Sedangkan keterampilan berkenaan tentang cara menerapkan sikap dan pengetahuan. Sedangkan Bajracharya (2010) mengembangkan model pembelajaran dengan nama model ABC. Istilah ABC merupakan akronim dari kata anticipation, building knowledge dan consolidation. Praktek model ABC, diantaranya; menugaskan siswa melakukan 
penyelidikan, memecahkan masalah, bekerja secara kooperatif, dan mengungkapkan ideide lisan yang diperoleh dari tulisan.

Berdasarkan kajian model-model pembelajaran, tampak bahwa peran siswa dalam model pembelajaran untuk membuat dan menyusun argumen tidak jelas pada setiap langkah-langkah pembelajaran. Sehingga diperlukan model pembelajaran yang baru, berkaitan membuat dan menyusun argumen untuk mengembangkan kemampuan berpikir kritis.

Pentingnya membelajarkan siswa membuat atau menyusun argumen untuk mengembangkan kemampuan berpikir kritis, diantaranya; Memudahkan seseorang terlibat dalam diskusi, mengkaji informasi-informasi dari berbagai sumber, mempertanyakan nilai kebenaran, dan mengajukan solusi (Aizikovitsh \& Amit, 2010; dan Rugeiro, 2012). Memudahkan seseorang mengkomunikasikan bukti-bukti, dan data-data pendukung, serta penjelasan cara memperolehnya (Schoenfeld, 2007; Duron, 2006; dan Gokhale, 2005). Mampu menilai kebenaran dan mempertanyakan solusi, menemukan ide-ide baru atau solusi lain, mengetahui dan memahami konsep-konsep yang saling terkait, dan saling bertukar pendapat dalam menjelaskan konsep (Williams \&Dickincon, 2012; dan Bacracharya, 2010).

Paparan hasil penelitian pendahuluan dan hasil-hasil penelitian diatas menunjukkan bahwa pembelajaran matematika yang selama ini menjadi sasaran utama dalam pembelajaran meliputi: konsep, fakta, dan operasi. Sedangkan objek-objek lain, seperti: pemecahan masalah, transfer belajar, kerja individu, dan kerja kelompok dianggap sebagai dampak pembelajaran saja, sehingga menarik untuk dikaji lebih mendalam secara teoretis atau empiris dalam bentuk model pembelajaran matematika yang mengembangkan kemampuan berpikir kritis disingkat model PMBK.

\section{Model Pembelajaran Matematika yang Mengembangkan Kemampuan Berpikir Kritis (PMBK)}

Bell (1981) menyatakan bahwa "a teaching/learning model is a generalized instructional process wich may be used for many different in a variety of subjects", artinya suatu model pembelajaran secara umum dapat diterapkan pada berbagai disiplin mata pelajaran. Joyce \& Weil (2009) menyatakan bahwa model pembelajaran merupakan petunjuk bagi guru dalam merencanakan pembelajaran, mempersiapkan perangkat pembelajaran, memilih media, dan melaksanakan evaluasi yang mengarah pada upaya 
pencapaian tujuan. Maksud pendapat tersebut bahwa model pembelajaran cocok untuk setiap mata pelajaran dan bertujuan untuk membantu guru melakukan kegiatan pembelajaran.

Selanjutnya, Joyce \& Weil (2009) mengemukakan bahwa ada 4 komponen penting dari suatu model pembelajaran, yaitu; sintak, sistem sosial, prinsip reaksi, dan sistem pendukung. Uraian masing-masing komponen adalah sebagai berikut.

\section{Sintak}

Hasil kajian beberapa teori belajar, teori berpikir kritis, dan model-model pembelajaran. Sintak model PMBK yang berhasil di desain terdiri dari 4 fase, yaitu: fase 1 mengidentikasi dan menjustifikasi konsep, fase 2 memecahkan masalah, fase 3 menggeneralisasi dan menganalisis algoritma, dan fase 4 kesimpulan. Untuk lebih jelasnya dapat dilihat pada tabel 1 berikut ini. 
Tabel 1. Sintak Model PMBK

\begin{tabular}{|c|c|c|}
\hline $\begin{array}{c}\text { Sintak model } \\
\text { PMBK }\end{array}$ & Kegiatan guru & Kegiatan siswa \\
\hline $\begin{array}{l}\text { Fase I: } \\
\text { mengidentifikasi } \\
\text { dan } \\
\text { menjustifikasi } \\
\text { konsep }\end{array}$ & $\begin{array}{l}\text { a. Guru membagi siswa kedalam } \\
\text { kelompok-kelompok kecil. } \\
\text { b. Menugaskan seluruh siswa } \\
\text { membaca materi atau kegiatan, } \\
\text { dan menentukan konsep-konsep } \\
\text { yang berkaitan pokok } \\
\text { permasalahan. } \\
\text { c. Menugaskan siswa menyusun } \\
\text { argument-argumen yang relevan } \\
\text { untuk menjelaskan konsep. } \\
\text { d. Menunjuk siswa secara bergantian } \\
\text { memberikan penjelasan tentang } \\
\text { konsep, dan mempertanyakan hal- } \\
\text { hal yang kurang jelas. }\end{array}$ & $\begin{array}{l}\text { a. Masing-masing siswa bergabung } \\
\text { dengan kelompok yang telah } \\
\text { ditentukan. } \\
\text { b. Membaca dan memahami isi materi } \\
\text { atau uraian kegiatan, dan menentukan } \\
\text { konsep-konsep yang berkaitan pokok } \\
\text { permasalahan. } \\
\text { c. Membuat argumen yang didukung } \\
\text { bukti-bukti untuk menguatkan } \\
\text { penjelasan. } \\
\text { d. Menguraikan secara jelas konsep- } \\
\text { konsep yang terdapat pada bahan ajar, } \\
\text { dan mempertanyakan hal-hal yang } \\
\text { kurang jelas }\end{array}$ \\
\hline $\begin{array}{l}\text { Fase II: } \\
\text { memecahkan } \\
\text { masalah }\end{array}$ & $\begin{array}{l}\text { a. Menugaskan siswa secara } \\
\text { berkelompok menyelesaikan } \\
\text { masalah yang terdapat pada } \\
\text { lembar kegiatan. } \\
\text { b. Menugaskan siswa pada masing- } \\
\text { masing kelompok untuk menilai } \\
\text { kebenaran jawaban. } \\
\text { c. Meminta penyaji untuk } \\
\text { memberikan tanggapan balik atas } \\
\text { pertanyaan yang diberikan. }\end{array}$ & $\begin{array}{l}\text { a. Merespon perintah guru dengan cara } \\
\text { menetapkan (diketahui, dan } \\
\text { ditanyakan), membuat model } \\
\text { matematika, dan penyelesaiannya. } \\
\text { b. Memberikan saran/komentar, dan } \\
\text { menilai kebenaran jawaban. } \\
\text { c. Memilih satu jawaban dan } \\
\text { menyerahkan kepada guru }\end{array}$ \\
\hline $\begin{array}{l}\text { Fase III: } \\
\text { menggeneralisasi } \\
\text { dan menganalisi } \\
\text { algoritma }\end{array}$ & $\begin{array}{l}\text { a. Menugaskan siswa menyajikan di } \\
\text { depan kelas. } \\
\text { b. Memberikan kesempatan kepada } \\
\text { siswa atau kelompok lain untuk } \\
\text { memberikan tanggapan atau } \\
\text { pertanyaan. } \\
\text { c. Mengarahkan kelompok penyaji } \\
\text { memberikan tanggapan balik atas } \\
\text { pertanyaan yang diberikan. }\end{array}$ & $\begin{array}{l}\text { a. Menyajikan hasil pekerjaan di depan } \\
\text { kelas (cukup kelompok yang terpilih). } \\
\text { b. Memeriksa, membandingkan jawaban } \\
\text { yang telah diperoleh, menghargai dan } \\
\text { mempertanyakan nilai kebenaran } \\
\text { jawaban. } \\
\text { c. Memberikan komentar balik dengan } \\
\text { cara melengkapi data pendukung, dan } \\
\text { memberikan penjelasan tambahan } \\
\text { beserta cara memperolehnya. } \\
\text { d. Merevisi hasil pemikiran yang } \\
\text { dianggap keliru }\end{array}$ \\
\hline $\begin{array}{l}\text { Fase } \\
\text { kesimpulan }\end{array}$ & $\begin{array}{l}\text { Menugaskan siswa } \\
\text { kesimpulan akhir. }\end{array}$ & $\begin{array}{l}\text { Membuat kesimpulan isi materi yang } \\
\text { telah dipejari. }\end{array}$ \\
\hline
\end{tabular}

\section{Sistem Sosial}

Sistem sosial model PMBK menganut pola hubungan yang berimbang antara guru dengan siswa atau siswa dengan siswa. Hubungan tersebut tercermin pada setiap fase model PMBK. Pada fase I siswa mengkonstruksi konsep-konsep, fakta-fakta, operasi, dan prinsip yang dikemas dalam sebuah uraian kegiatan sebagai upaya untuk mengetahui dan memahami materi matematika. Fase II siswa bekerjasama dalam menyelesaikan tugastugas yang diberikan dengan cara mengidentifikasi masalah (diketahui, dan ditanyakan), membuat model matematika, dan penyelesaiannya. Fase III siswa mendalami suatu sajian 
permasalahan dengan cara memeriksa/memperbaiki langkah penyelesaian yang kurang tepat, melengkapi data-data pendukung yang dianggap kurang, dan memberikan penjelasan cara memperolehnya dari setiap prosedur pemecahan masalah. Fase IV siswa membuat ringkasan materi yang diungkapkan oleh siswa sendiri, menilai dan mengevaluasi proses yang telah dilakukan. Sedangkan guru cukup memberikan saran-saran perbaikan terkait kesimpulan.

\section{Prinsip Reaksi}

Adapun prinsip reaksi dalam model PMBK, antara lain: (1) memberikan kesempatan kepada siswa untuk bereksplorasi, memberikan kesempatan kepada siswa melakukan prediksi dan hipotesis, mencoba solusi lain dan mendiskusikannya. (2) memberikan kesempatan kepada siswa lain untuk menyajikan dan merefleksikan temuantemuan didepan kelas. (3) Mengarahkan siswa menjawab masalah yang terdapat pada lembar tugas, menyampaikan langkah penyelesaian, memberikan penjelasan pada setiap algoritma, memonitorin, dan memeriksa kembali selesaian. (4) Menghargai segala aktivitas siswa yang mendukung proses pembelajaran dan mengarahkan aktivitas siswa yang menghambat proses pembelajaran.

\section{Sistem Pendukung}

Beberapa sistem pendukung pada model PMBK, diantaranya; perangkat pembelajaran yang terdiri dari: rencana pembelajaran, bahan ajar, dan lembar kegiatan siswa. Rencana pembelajaran terdiri dari empat komponen, yaitu (1) pertanyaan atau tugas guru, komponen ini berisi perintah atau suruhan guru kepada siswa, (2) respon atau jawaban siswa yang diharapkan, komponen ini berisi jawaban atau respon terhadap perintah guru, (3) reaksi guru atas jawaban siswa, komponen ini berisi reaksi guru terhadap jawaban siswa terkait pertanyaan yang diajukan, dan (4) refleksi/catatan guru.

Bahan ajar (BA) dirancang untuk mengajak siswa mengetahui dan memahami konsep dalam matematika, menyajikan hasil-hasil temuannya, menggunakan algoritma, dan menggenaralisasi keterampilan teknis. Sedangkan Lembar kegiatan siswa (LKS) yang dirancang khusus menuntut siswa belajar matematika yang relevan dengan masalah atau tugas yang diberikan. Pada bagian lembaran LKS disiapkan kolom kerja, sebagai tampat atau kolom jawaban bagi siswa untuk menuliskan hasil pekerjaannya. 


\section{METODE PENELITIAN}

Model pembelajaran yang akan dikembangkan mengacu pada tahap-tahap pengembangan model yang dikemukakan oleh Plomp (2013), yakni: (a) identifikasi masalah dan analisis kebutuhan, (b) perancangan dan implementasi, dan (c) evaluasi.Sedangkan komponen-komponen yang tercakup dalam model PMBK mengacu kepada komponen-komponen model pembelajaran yang dikemukakan Joice, \& Weil (2009),yaitu: (a) sintaks, (b) sistem sosial, (c) prinsip reaksi, dan (d) sistem pendukung. Sedangkan kriteria kualitas model pembelajaran yang dikembangkan mengacu pada Nieveen (2013) yaitu valid, praktis, dan efektif. Adapun tahapan atau prosedur pelaksanaan penelitian pengembangan model PMBK dapat ditunjukkan pada gambar berikut: 


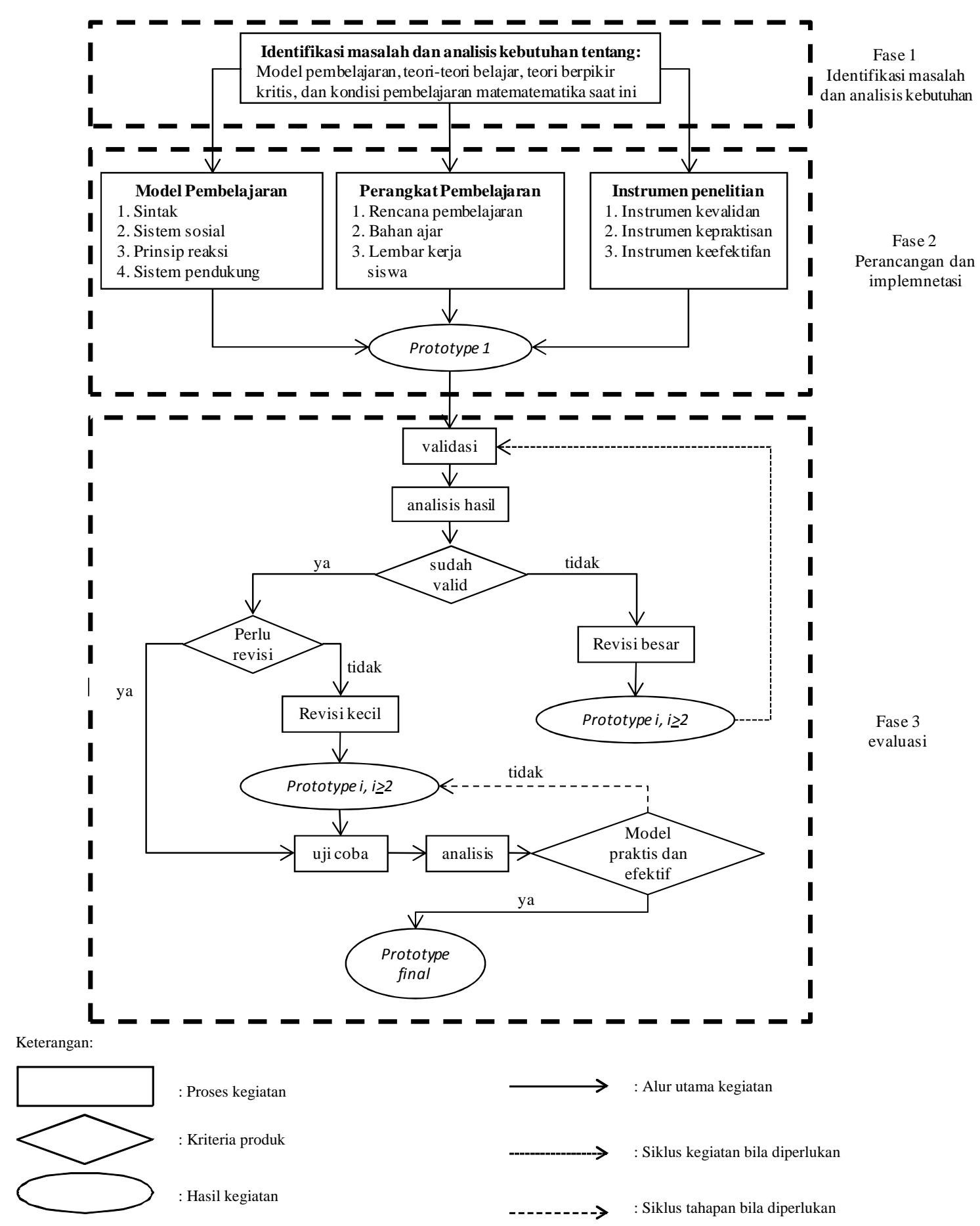

Gambar 1. Alur Kegiatan Pengembangan Model PMBK

\section{PEMBAHASAN}

Hasil uji validasi dan uji coba model PMBK menunjukkan bahwa model PMBK telah memenuhi kriteria valid, praktis dan efektif. Hasil-hasil tersebut diperoleh melalui prosedur pengembangan produk menurut Plomp (2013) yang telah dimodifikasi dengan 
memasukkan komponen-komponen model menurut Joyce \& Weil (2009) dan indikator kwalitas produk oleh Nieeven (2013).

Hasil penelitian dan pengembangan ini memperkuat temuan-temuan sebelumnya, diantaranya: Hasil penelitian Paul \& Elder (2008) dengan judul "Using Critical Thinking to Foster Student Learning and Community Engangement". Watson \& Glaser (2008) dengan judul "Critical Thinking Appraisal" yang mengembangkan standar berpikir kritis dan indikator penilaian berpikir kritis. Hasil penelitian Bajracharya (2010) dengan judul "Teaching Mathematics Through ABC Model of Critical Thinking". Model ABC merupakan akronim dari kata Anticipation, Building knowledge dan Consolidation. Penelitian Sherlin (2008) dengan judul "Improved Critical Thinking Skills as a Result of Direct Instructional and Their Telationship to Academic Achivement", dan penelitian Gokhale (2005) dengan judul “collaborative learning enhances critical thinking”.

Hal penting yang dikemukakan dari keempat peneliti tersebut, antara lain: (1) Setiap pembelajaran perlu melibatkan objek-objek kajian yang mendukung seseorang untuk berpikir kritis, dan menjadikan sebagai tujuan utama pembelajaran. (2) objek kajian belajar matematika merupakan salah satu sarana dalam berpikir kritis. (3) interaksi sosial dan kerja kolaboratif dapat mengembangkan kemampuan berpikir kritis.

Adapun pembahasan hasil pengembangan model PMBK pada pembelajaran matematika difokuskan pada sintak model PMBK, yaitu: mengidentifikasi dan menjustifikasi konsep, memecahkan masalah, menganalisis algoritma dan menggeneralisasi, dan kesimpulan. Pembahasan dari masing-masing adalah sebagai berikut.

\section{Mengidentifikasi dan Menjustifikasi Konsep}

Pada kajian sebelumnya telah dijelaskan bahwa indikator kemampuan berpikir kritis pada fase mengidentifikasi dan menjustifikasi konsep adalah siswa memilih atau menetapkan konsep yang utama, kemudian memberikan penjelasan dengan kata-katanya sendiri yang lengkap, dan bernilai benar. Pencapaian indikator ini ditempuh melalui aktifitas membaca dan memahami uraian kegiatan yang terdapat pada bahan ajar, selanjutnya menginterpretasi dan membuat asumsi, kemudian menjelaskan kepada kawankawanya.

Beberapa faktor pendukung perkembangan kemampuan berpikir kritis pada tahap mengidentifikasi dan menjustifikasi konsep, antara lain; (1) pemberian kebebasan kepada 
siswa untuk melakukan eksplorasi dan membangun pengetahuan, (2) uraian kegiatan yang terdapat pada bahan ajar, mengarahkan siswa untuk mencari tahu informasi-informasi dengan caranya masing-masing, memacu siswa untuk berdiskusi dan tanya jawab, (3) pemberian kesempatan kepada siswa untuk menyajiakan temuannya didepan kawan sekelompoknya.

Hasil ini memperkaya temuan sebelumnya; seperti Gokhale (2005), dan Bajracharya (2010). Gokhale (2005) mengkombinasikan membaca, dan memahami uraian materi, serta interaksi sosial untuk berpikir kritis. Sedangkan temuan penulis dalam penelitian ini lebih spesifik yaitu mencari informasi-informasi, kemudian menetapkan konsep-konsep yang dianggap penting, serta memberikan penjelasan dengan kata-katanya sendiri.

Temuan ini sejalan hasil penelitian Bajracharya (2010) menyatakan bahwa mengembangkan kemampuan berpikir kritis siswa dapat dilakukan dengan cara memberikan waktu yang cukup kepada siswa untuk membangun pengetahuan dengan memperbanyak membaca dan memahami konsep, serta merefleksi segala temuan-temuan. Dengan dmeikian dapat disimpulkan bahwa aktivitas mengidentifikasi dan menjustifikasi merupakan kegiatan yang dapat memperkuat pengetahuan tentang sumber-sumber kognitif dan pemecahan masalah.

\section{Memecahkan masalah}

Indikator kemampuan berpikir kritis pada fase memecahkan masalah adalah mengidentifikasi soal (diketahui, ditanyakan, kecukupan unsur) dan membuat model matematika dengan benar, kemudian penyelesaiannya dengan benar. Pada fase ini siswa ditugaskan untuk berpikir membuat solusi atau jawaban, dan membuat gagasan, menyampaikan pendapat atau ide.

Selain itu, siswa bekerja secara kolaboratif untuk memecahkan masalah. Bekerja secara kolaboratif yaitu melakukan pekerjaan dengan cara menggabungkan berbagai potensi yang berbeda untuk memecahkan masalah. Temuan ini memperkaya temuan Stacey (2013) menyatakan bahwa partisipasi seluruh siswa atau rekan-rekan dalam kelompok dapat membantu membuat pemecahan masalah yang kebenarannya dapat dipercaya dan diyakini. Demikian juga, Gokhale (2005) menyatakan bahwa bekerja secara kolaboratif dapat meningkatkan hasil belajar, khususnya dari sisi proses dan penguasaan materi pelajaran. 


\section{Menganalisis Algoritma dan Menggeneralisasi.}

Indikator berpikir kritis pada fase menggeneralisasi dan menganalisisi algoritma ada 2 yaitu: (1) siswa mampu memeriksa, memperbaiki, dan memberikan penjelasan setiap langkah algoritma pemecahan masalah dengan lengkap dan benar, dan (2) siswa mampu melengkapi data pendukung, menentukan aturan umum, dan memberikan penjelasan tentang cara memperolehnya dengan lengkap dan benar.

Gambaran kemampuan berpikir kritis pada indikator 1, meliputi: siswa terampil menganalisis berbagai solusi atau jawaban berdasarkan alur atau prosedur yang telah dilakukan sebelumnya, dan dapat memberikan sumbangan gagasan, pendapat atau ide. Pada fase ini, menganalisis algoritma dianggap berguna oleh sebagian besar siswa, sebagai sarana untuk memahami hasil kerja diri dan orang lain.

Temuan ini relevan dengan hasil penelitian sebelumnya, seperti; Glaser (2001) menyatakan bahwa penerapan diskusi, eksplorasi, dan penyelidikan dalam kegiatan pembelajaran merupakan kegiatan penting untuk berpikir kritis. Sejalan King \& Goodson (2010) menyatakan bahwa mengembangkan kemampuan berpikir kritis siswa, guru perlu memfasilitasi siswa untuk melakukan analisis dan refleksi diri. Kegiatan menganalisis algoritma merupakan alur yang dapat mengintegrasikan pemahaman siswa yang telah diperoleh dengan tindakan-tindakan yang lebih baik, serta memperkuat efektivitas pembelajaran.

Gambaran kemampuan berpikir kritis siswa pada indikator 2, yaitu mampu melengkapi data pendukung dan menentukan aturan umum, serta memberikan penjelasan cara memperolehnya dengan lengkap dan benar. Siswa terampil melakukan pengkaitan antara suatu konsep dengan konsep lain, dan mengaplikasikan konsep tersebut pada permasalahan-permasalahan, dan belajar matematika lebih mandiri kapan saja dan dimana saja.

Beberapa manfaat menggeralisasi, antara lain: dapat meningkatkan penguasaan materi matematika, siswa lebih cepat dan mudah memahami materi, menemukan keterkaitan antar konsep, dan mampu mengaplikasikan konsep yang telah dipahami pada bidang lain.

Hasil-hasil penelitian ini memperkaya temuan sebelumnya, diantaranya: Duron, Limbach, \& Waugh (2006) menyatakan bahwa melengkapi data-data pendukung pada suatu jawaban dapat menambah wawasan dan penguasaan materi matematika lebih baik. 
Respon siswa dalam memberikan penjelasan cara memperolehnya atas jawaban mereka, dapat mendorong minat belajar baik secara mandiri maupun kelompok.

\section{KESIMPULAN}

Proses pengembangan model PMBK mengacu pada teori pengembangan produk yang dikemukakan oleh Plomp (2013) terdiri 3 fase, yaitu; (a) fase identifikasi masalah dan analisis kebutuhan, (b) fase perancangan dan implemetasi, dan (c) fase evaluasi.

Penelitian ini menghasilkan beberapa produk pendidikan yang telah memenuhi kriteria valid, praktis, dan efektif, yaitu; (1) model pembelajaran matematika yang mengembangkan kemampuan berpikir kritis, disingkat model PMBK, (2) perangkat pembelajaran (rencana pembelajaran, bahan ajar, dan LKS) yang disusun berdasarkan model PMBK, dan (3) instrumen-instrumen penelitian terkait proses pengembangan.

Adapun hasil-hasil kajian produk yang telah direvisi antara lain:

1. Sintak model PMBK, meliputi: mengidentifikasi dan menjustifikasi konsep, memecahkan masalah, menggeneralisasi dan menganalisis algoritma, dan kesimpulan. Hasil-hasil yang diperoleh dengan menggunakan sintaks tersebut pada masing-masing uji coba dikemukakan berikut ini.

Uji coba I

Hasil yang dicapai pada uji coba I yaitu model PMBK belum memenuhi kriteria praktis dan efektif. Hal ini terlihat 2 indikator kepraktisan belum tercapai, yaitu: keterlaksanaan model PMBK secara umum dalam kategori sebagian kecil terlaksana, dan aktivitas siswa yang diharapkan belum terpenuhi. Indikator terpenuhi yaitu kemampuan guru mengelola pembelajaran dalam kategori baik dan respon siswa positif. Sedangkan indikator keefektifan yaitu skor penilaian kemampuan berpikir kritis dalam pembelajaran dan skor tes kemampuan berpikir kritis dalam memehami materi belum memenuhi kriteria keefektifan.

Uji coba II

Hasil yang dicapai pada uji coba II yaitu model PMBK belum memenuhi kriteria praktis dan efektif. Hal ini terlihat satu indikator kepraktisan model PMBK belum tercapai, yaitu: aktivitas siswa yang diharapkan model PMBK belum terpenuhi. Sedangkan indikator lain yang sudah terpenuhi yaitu keterlaksanaan komponen model secara umum dalam kategori sebagian besar terlaksana, kemampuan guru mengelola pembelajaran dalam kategori baik, dan respon siswa positif. Sedangkan indikator 
keefektifan yaitu skor penilaian kemampuan berpikir kritis dalam pembelajaran dan skor tes kemampuan berpikir kritis dalam memehami materi belum memenuhi kriteria keefektifan.

Uji coba III

Hasil yang dicapai uji coba III yaitu model PMBK telah memenuhi kriteria praktis dan efektif. Hal ini terlihat semua indikator kepraktisan model PMBK telah tercapai, yaitu: (1) keterlaksanaan komponen model secara umum dalam kategori sebagian besar terlaksana atau terlaksana seluruhnya, (2) aktivitas siswa yang diharapkan model PMBK telah terpenuhi, (3) kemampuan guru mengelola pembelajaran dalam kategori baik atau sangat baik, dan (4) respon siswa positif. Demikian juga indikator keefektifan terlihat bahwa skor penilaian kemampuan berpikir kritis dalam pembelajaran dan skor tes kemampuan berpikir kritis dalam memahami materi telah memenuhi kriteria keefektifan. Dengan demikian model PMBK yang dikembangkan telah memenuhi kriteria valid, praktis, dan efektif.

2. Beberapa temuan ikutan yang berkontribusi dalam penelitian ini antara lain: pada pelaksanaan uji coba I dan II terdapat beberapa jenis aktivitas siswa yang menggunakan waktu yang relatif lama antara lain: (1) menjelaskan konsep, dan prinsip belajar matematika; (2) mengidentifikasi soal (diketahui, ditanyakan, kecukupan unsur), membuat model matematika, dan penyelesaiannya; (3) memeriksa, memperbaiki, dan memberikan penjelasan setiap langkah algoritma pemecahan masalah; (4) siswa secara individu atau kelompok mempersentasikan pendapat/ide di depan kelas. Akibatnya ketercapaian waktu ideal tidak tercapai. Namun pada uji coba III berangsur-angsur membaik hingga semua aktivitas siswa sebagian besar terlaksana/terlaksana seluruhnya.

3. Temuan lain yang berkontribusi dalam penelitian ini, antara lain: (1) keseriusan dan semangat guru mempelajari dan memahami secara detail tekhnis pelaksanaan model PMBK, dan (2) adanya kemauan guru melakukan simulasi di kelas yang berbeda sebelum pelaksanaan uji coba pada kelas yang telah tentukan.

4. Fenomena lain yang menarik terjadi pada kemampuan berpikir kritis dan respon siswa. Kemampuan berpikir kritis ditinjau proses pelaksanaan beransur-angsur membaik, sedangkan respon siswa terhadap pelaksanaan model PMBK ternyata pada uji coba I, II, dan III memberikan respon positif atau di atas $75 \%$ jumlah aspek yang ditanyakan. 


\section{REKOMENDASI}

Sedangkan saran yang dapat diberikan dari penelitian ini, yaitu:

1. Model PMBK yang dikembangkan ini baru sampai pada tahap uji coba terbatas pada 3 kelas, oleh sebab itu untuk mengetahui keefektifannya pada lingkup yang lebih luas, disarankan kepada para peminat untuk mengimplementasikannya di sekolah-sekolah.

2. Aspek-aspek berpikir kritis siswa yang diterapkan dalam model PMBK ini dapat dimodifikasi oleh para guru yang berminat menerapkan model ini, modifikasi dapat dilakukan dengan menyesuaikan dengan lingkungan dan budaya siswa. Dengan demikian perangkat-perangkat model PMBK juga turut termodifikasi.

\section{REFERENSI}

Aizikovitsh, E. A., M. In P. Brosnan, P. Erchick, D. B., \& Flevares, L. (eds.) (2010). Is It Possible to Improve the Students Critical Thinking Dispositions Through Teaching a Course In Probability. Proc. 32nd Annual Meeting of the North American Chapter of the International Group for the Psychology of Mathematics Education. $\mathrm{OH}$ : The Ohio State University. (2011, Maret 17). Diperoleh dari http://www.pmena.org/proceedings/PMENA32010/Proceedings.pdf

Arends, R. L. (1997). Classroom Instruction and Management. New York: McGraw-Hill Book Co.

Bajracharya, I. K., B. (2010). Teaching Mathematics Through ABC Model of Critical Thinking. Mathematics Education Forum. Vol. II, issue 28, year 14, pp: 13-17. Thachal Kathmandu: Mahendra Ratan Campus.

Beagle. (1980). A Darwinian Approach to Pattern Recognition. London: Departement of Mathematics, Polytechnic of North London. (2012, Maret 12). Diperoleh dari http://www0.cs.ucl.ac.uk/staff/ucacbbl/ftp/papers/kybernetesforsyth.pdf

Bell, T. (1978). A New Approach to Quantum Logic. British Journal for Philosophy of Science. Vol. 37, pp: 83-99. (2012, Maret 14). Diperoleh dari https://books.google.com/book/ANewApproachtoQuantumLogic

Berki, E. \& Valtanen, J. (2007). Critical and Creative Mathematical Thinking with Practical Problem Solving Skills A New Old Challenge. pp: 265-289. Hershey, PA, USA: Idea Group Publishing. (2012, Januari 16). Diperoleh dari 
http://www.google.com/url?CriticalandCreativeMathematicalThinkingwithPractical ProblemSolvingSkillsANewOldChallenge.pdf

Campbell, S., R. (2004). Embodied Minds and Dancing Brains: New Opportunities for Research in Mathematics Education. Canada: Faculty of Education, Simon Fraser University. (2013, Juli 14). Diperoleh dari https://books.google.com/books=campbell+2004+thinking\&source=bl\&ots=WTaC FcUWuH\&sig=Utf83a8AbiIC3tPpzT3Y6M77kZo\&hl=id\&sa=X\&ei=r66nVNf0E Mz5auegfgO\&ved=0CFkQ6AEwCzgK\#v=onepage\&q=campbell\%202004\%20thin king $\& \mathrm{f}=$ false

Dickerson \& Doerr. (2008). International Group for the Psychology of Mathematics Education. Proceedings of the Joint Meeting of PME 32 and PMENA XXX. Centro de Investigacion the Estudios Avanzados del IPN. San Nicolás de Hidalgo: Universidad Michoacana. (2013, Februari 23). Diperoleh dari http://www.pmena.org/proceedings/PMENA203020200820Proceedings20Vol201.p df

Duron, R., Limbach, B., \& Waugh, W. (2006). Critical Thinking Framework. In International Journal of Teaching and Learning in Higher Education. Vol. 17, no. 2, 160-166. Virgilance: Illinois State University. (2011, Mei 6). Diperoleh dari http://www.isetl.org/ijtlhe/pdf/IJTLHE55.pdf

Ennis, R. H. (2007). Probable and its equivalents., Reason reclaimed. Newport News, VA: Vale Press. pp: 243-256. (2012, Januari 14). Diperoleh dari http://www.criticalthinking.net/articles.html

Ennis, R. H. (2008). Nationwide Testing of Critical Thinking for Higher Education. Teaching Philosophy. pp: 1-26. Vigilance: University of Illinois UC. (2012, Maret 27). Diperoleh dari http://www.criticalthinking.net/NatCTTest111807U.pdf

Facione P. (2011). Critical Thinking: What It Is and Why It Counts. pp: 1-28. Millbrae. CA: California Academic Press. (2012, Maret 17). Diperoleh dari http://spu.edu/depts/ sciences/grad/documents/CTbyFacione.pdf

Fisher, A. (2001). Critical Thinking in Introduction. Australia: Cambridge University Press. (2011, Desember 14). Diperoleh dari http://www.enopinapervilleaurora.com/CTdefinition.pdf

Glaser, E. (2001). Advanced School of Education at Teacher's College. An Experiment in the Development of Critical Thinking, pp: 1-86.Columbia: Columbia University. 
(2013, Februari 24). Diperoleh dari

http://www.worldcat.org/title/experimentinthedevelopmentofcriticalthinking/oclc/3 5678624

Gokhale, A. (2005). Collaborative Learning Enhances Critical Thinking. Journal of Technology Education. Vol. 7, No. 1 Fall 2005. Virgilance: The Department of Industrial Education and Technology Illinois State University. (2011, Januari 14) Diperoleh dari http://scholar.lib.vt.edu/ejournals/JTE/v7n1/gokhale.jtev7n1.html Innabi, H. (2003). Aspects of Critical thinking in Classroom Instruction of Secondary School Mathematics Teachers in Jordan. The Mathematics Education into the 21st Century Project. Proceeding of The International Conference. The Decidable and the Undecidable in Mathematics Education. pp: 124-129. Jordan: Brno, Czech Republic. (2012, Maret 14). Diperoleh dari http://math.unipa.it/ grim/21project/21brno03Innabi.pdf

Joyce, B., dkk. (2009). Models of Teaching. $8^{\text {th }}$ Edition. USA: Allyn and Bacon. Kementerian Pendidikan dan Kebudayaan. 2013. Kurikulum 2013. Jakarta: Badan Penelitian dan pengembangan.

King, F. J., \& Goodson, L. (2010). Higher Order Thinking Skills. A publication of the Educational Services Program, now known as the Center for Advancement of Learning and Assessment. (2013, April 13). Diperoleh dari http://www.cala.fsu.edu/files/higherorderthinkingskills.pdf

Marcut, I. (2005). Critical thinking Applied to the Methodology of Teaching Mathematic. Vol. 1, 57-66. Educatia Matematica. (2012, September). Diperoleh dari http://depmath.ulbsibiu.ro/educamath/em/vol1nr1/marcut/marcut.pdf

Mason, J., Burton, L., \& Stacey, K. (2010). Thinking Mathematically. Second edition. England: Pearson Education Limited. (2013, Agustus 23). Diperoleh dari http://www.google.com/url.d24

Nieveen. N. (2013). Educational Design Research: Netherlands: Netherlands Institute for Curriculum Development (SLO). (2014, Oktober 14). Diperoleh dari http://www.fi.uu.nl/publicaties/literatuur/EducationalDesignResearch.pdf Nurdin, (2007). Model Pembelajaran Matematika yang Menumbuhkan Kemampuan Metakognitif untuk Menguasai Bahan Ajar. Disertasi. Surabaya. PPS UNESA. 
Paul, R. \& Elder, L. (2005). Critical thinking and the art of substantive writing. (Part I). Journal of Developmental Education. 29 (1). 40-41. (2012, Agustus 21). Diperoleh dari http://www.ucumberlands.edu/qep/articles.htm

Paul, R., \& Elder, L. (2008). Ideas to Action: Using Critical Thinking to Foster Student Learning and Community Engangement. Journal of Developmental Education. (2012, November 28). Diperoleh dari https://louisville.edu/ideastoaction//files/final-report.pdf

Plomp, T. (2013). Educational Design Research. Netherlands: Netherlands Institute for Curriculum Development (SLO). (2014, September 14). Diperoleh dari http://www.fi.uu.nl/publicaties/literatuur/EducationalDesignResearch.pdf

Rantzer A., Christopher, I., \& Byrnes, C. (eds.). (2003). Directions in Mathematical Systems Theory and Optimization. Verlag Berlin Heidelberg NewYork: Springer. (2013, Maret 14). Diperoleh dari http://nozdr.ru/data/media/biblioteka/kolxo3/MMathematics/MOc.pdf

Reys, R. E. \& Lindquist, M. (2013). Helping Children Learn Mathematics, First Australian Edition. Australian. (2014, September 15). Diperoleh dari http://www.wileydirect.com.au/buy/helpingchildrenlearnmathematics1staustraliane dition/

Ruggiero, V. R. (2012). Beyond Feelings: A Guide to Critical Thinking. Ninth Edition. New York: The McGraw-Hill Companies, Inc. (2015, 29 Januari). Diperoleh dari http://www.kwcps.k12.va.us/userfiles/270/Classes/4893/VRRuggieroBeyondFeelin gs9thedition.pdf

Stacey K. (2013). Mathematical Thinking: A Capabilities Approach to What is, How to Measure it, and Research Possibilities. Makalah yang disajikan di Konferensi Pendidikan Matematika ke 5, tanggal 27-30 juli 2013, di Universitas Negeri Malang.

Watson, G. \& Glazer, E. M. (2008). Watson Glaser Critical Thinking Appraisal. United States of America. Pearson Education. (2013, Januari 19). Diperoleh dari http://www.talentlens.co.uk/assets/newsandevents/watsonglaseruserguideandtechni calmanual.pdf

Williams, L \& Dickincon, H. (2012). Can Knowledge Management Enhance Technology Adoption in Healthcare. A Review of the literature. Evidence and Policy. Vol. 6. 
No. 3. 309332. The Policy Press. (2013, Mei 25). Diperoleh dari

http://www.ncbi.nlm.nih.gov/books/NBK259893 
